\section{Split and Tank-mix Preemergence Application of Herbicide for Controlling Weeds in Grapes}

\author{
Martin L. Kaps ${ }^{1}$ and Marilyn B. Odnea1 ${ }^{2}$ \\ Department of Fruit Science, Southwest Missouri State University, Mountain \\ Grove, $M O 65711$
}

Additionial index words. Vitis spp., diuron, norflurazon, oryzalin, oxyfluorfen, simazine

\begin{abstract}
Spring vs. fall plus spring (split) herbicide application times and single vs. tankmix spring herbicide applications were compared as a means of extending summer annual weed control in vineyards. About $30 \%$ of the nontreated control areas were weed-covered by April or May of each of 3 years. Most treatments gave 60 or more days of acceptable annual weed control ( $\leq \mathbf{3 0 \%}$ cover) beyond the nontreated control. Fall plus spring application of diuron, norflurazon, or simazine at the half-label rate did not increase the days of control over spring application alone at the full-label rate. The tank-mixed herbicides diuron, norflurazon, and oryzalin in combinations of any two at the half-label rate were as effective as the full-label rate of these herbicides used alone. Weed control by oxyflurofen or simazine was extended by tank-mixing with oryzalin (half-label rates). Chemical names used: $N$-(3,4-dichlorophenyl) $-N, N$-dimethylurea (diuron); 4-chloro-5(methylamino)-2-(a,a,a-trifluoro-m-tolyl)-3(2 H) - pyridazinone (norflurazon); 3,5-dinitro$\mathrm{N}^{4}, \mathrm{~N}^{4}$-dipropyl-sulfanilamide (oryzalin); 2-chloro-l-(3-ethoxy -4-nitrophenoxy )-4(trifluoromethyl) benzene (oxyfluorfen); and 2-chloro-4,6-bis(ethylamino)-s-triazine (simazine).
\end{abstract}

A common practice in Missouri vineyards is to maintain bare soil under the grape trellis and grass sod in the row middles. Weeds under the trellis are controlled with preemergence and postemergence herbicide applications in the spring. If the preemergence herbicide degrades and postemergence treatment is not used later in the season, summer and winter annual weeds will establish. This weed residue forms a barrier to preemergence application of herbicide the following spring. Previous work showed that Missouri mowers cannot rely on herbicide applied preemergence in the fall to give extended control of summer annual weeds the next season, although winter annual weeds were controlled (Kaps and Odneal, 1991). The objective of these experiments was to compare spring vs. fall plus spring (split) herbicide application times and single vs. tank-mix spring herbicide applications for controlling summer and winter annual weeds.

\section{Materials and Methods}

The experiments were conducted from Fall 1987 through Summer 1990 in vineyards at Southwest Missouri State Univ. Research Campus at Mountain Grove. Vineyards were planted in 1968 to 'Catawba' and in 1978 to 'Aurore', 'Baco Noir', 'Catawba', 'Chancel-

\footnotetext{
Received for publication 25 June 1993. Accepted for publication 1 Dec.1993. The cost ofpublishing this paper was defrayed in part by the payment of page charges, Under postal regulations, this paper therefore must be hereby marked advertisement solely to indicate this fact.

'AssociateResearchProfessor.

${ }^{2}$ ResearchAssociate.
}

lor', 'Chelois', 'Concord', and 'Sevval Blanc'. Grapevines were trained to a Four-Arm Kniffin system and balance-pruned (Cahoon et al., 1991 ). Soil type was a Viraton cherty silt loam with $1.8 \%$ organic matter and $\mathrm{pH}$ 6.6. The topsoil was of shallow depth and underlain by fragipan. The vineyards were not irrigated, and yield was not taken due to low vine vigor. Canopies were not dense, thereby allowing full sunlight to reach the ground under the trellis during a portion of the day. Spring herbicide treatments were applied at the fulllabel rate for this soil type and at half-label rate each for fall plus spring treatments. The exwith four replications. Each replication consisted of five to 10 grapevines $(1.2 \times 12.2$ to 24.4-m area) depending on year and experiment. Vines were spaced at $2.4 \mathrm{~m}$ within rows and $3.1 \mathrm{~m}$ between rows. Herbicides were applied to both sides of the trellis row with a overlapping 10 to $15 \mathrm{~cm}$ in the center. Spray volume was 608 liters $\cdot \mathrm{ha}^{-1}$. Vegetation between rows was tall fescue (Festuca arundinacea Schreb.) and Kentucky bluegrass (Pea pratensis L.) sod that was mowed perperiments were randomized complete blocks single, flat fan nozzle spraying a $60-\mathrm{cm}$ swath fall plus spring (split) herbicide application times. odically. Fall applications were made in late Nov. or early Dec. 1987, 1988, and 1989. Spring applications were made in late Feb. or early Mar. 1988, 1989, and 1990. The controls received no herbicide treatment. The percentage of total weed cover was estimated visually the fourth week of every month from April through September. The number of days of $\leq 30 \%$ total weed cover was interpolated between the observation dates. An analysis of variance $(P<0.05)$ was done within years and with years combined as replications. Results were tabulated as days of acceptable annual weed control beyond the nontreated control. Duncan's multiple range test $(P \leq 0.05)$ was used for mean separation.

\section{Results and Discussion}

Predominant annual broadleaf weed species in the vineyards were Carolina geranium (Geranium carolinianum L.), common chickweed [Stellaria media (L.) Cyrillo.], common ragweed (Ambrosia artemisiifolia L.), corn speedwell (Veronica arvensis L.), henbit (Lamium amplexicaule L.), horseweed (Erigeron canadensis L.), purslane speedwell (Veronica peregrina L.), shepherdspurse [Capsella bursa-pastoris (L.) Medic.], Virginia pepperweed (Lepidium virginicum L.), and yellow rocket (Barbarea vulgaris $\mathrm{R}$. Br.). Annual grass weeds were smooth crabgrass [Digitaria ischaemum (Schreb.) Muhl.] and yellow foxtail [Setaria, glauca (L.) Beauv.].

About $30 \%$ of the nontreated control areas were weed-covered by 21 May 1988, 18 Apr. 1989, and 27 May 1990. Most of the treatments gave 60 or more days of acceptable annual weed control beyond the nontreated control (Tables 1 and 2). Exceptions to this occurred in all years. This number of days of control kept vineyards from having substantial weed cover until midsummer.

In 1988, there were no significant differences in the days of acceptable annual weed control among herbicides or between spring and fall plus spring (split) application times (Table 1). In 1989, spring application of herbicide showed a nonsignificant trend toward more days of control than fall plus spring application; this was probably due to the early weed growth that occurred in the nontreated controls that year. In 1990, significant differences occurred only among herbicides and not between application times. The winter annual broadleaf weeds common chickweed, corn speedwell, purslane speedwell, Virginia pepperweed, and yellow rocket were usually

Table 1. Days of acceptable annual weed control ( $\leq 30 \%$ cover) beyond the nontreated control for spring and

\begin{tabular}{|c|c|c|c|c|c|c|}
\hline \multicolumn{3}{|c|}{ Treatment } & \multicolumn{4}{|c|}{ Year } \\
\hline \multirow{2}{*}{$\begin{array}{l}\text { Herbicide and } \\
\text { formulation }\end{array}$} & \multicolumn{2}{|c|}{ Rate a.i. $\left(\mathrm{kg} \cdot \mathrm{ha}^{-1}\right)$} & 1988 & 1989 & 1990 & $1988-90$ \\
\hline & $\overline{\text { Fall }}$ & Spring & \multicolumn{4}{|c|}{ Days of control } \\
\hline \multirow[t]{2}{*}{ Diuron 80W } & $\cdots$ & 5.4 & $71 a^{\prime}$ & $115 \mathrm{a}$ & $83 a$ & $89 a$ \\
\hline & 2.7 & 2.7 & $87 \mathrm{a}$ & $79 a-c$ & $66 \mathrm{a}$ & $77 \mathrm{ab}$ \\
\hline \multirow[t]{2}{*}{ Norflurazon 80WP } & $\ldots$ & 4.5 & $73 a$ & $110 \mathrm{ab}$ & $11 \mathrm{~b}$ & $65 \mathrm{bc}$ \\
\hline & 2.2 & 2.2 & $89 a$ & $69 \mathrm{bc}$ & $23 \mathrm{~b}$ & $60 \mathrm{bc}$ \\
\hline \multirow[t]{2}{*}{ Simazine $80 \mathrm{~W}$} &.-- & 5.4 & $73 a$ & $72 a-c$ & $28 \mathrm{~b}$ & $57 \mathrm{c}$ \\
\hline & 2.7 & 2.7 & $85 a$ & $53 \mathrm{c}$ & $22 b$ & $54 \mathrm{c}$ \\
\hline
\end{tabular}

"Mean separation in columns by Duncan's multiple range test, $P \leq 0.05$. 
Table 2. Days of acceptable annual weed control ( $\leq 30 \%$ cover) beyond the nontreated control for single and tank-mix spring herbicide applications.

\begin{tabular}{|c|c|c|c|c|c|}
\hline \multicolumn{2}{|c|}{ Treatment } & \multicolumn{4}{|c|}{ Year } \\
\hline \multirow{2}{*}{$\begin{array}{l}\text { Herbicide and } \\
\text { formulation }\end{array}$} & \multirow{2}{*}{$\begin{array}{l}\text { Rate a.i. } \\
\left(\mathrm{kg}^{\circ} \mathrm{ha}^{-1}\right)\end{array}$} & 1988 & 1989 & 1990 & $1988-90$ \\
\hline & & \multicolumn{4}{|c|}{ Days of control } \\
\hline Diuron $80 \mathrm{~W}$ & 5.4 & $69 a-c^{7}$ & $63 \mathrm{a}$ & $65 \mathrm{ab}$ & $66 \mathrm{bc}$ \\
\hline Norflurazon 80WP & 4.5 & $59 \mathrm{bc}$ & $78 \mathrm{a}$ & $57 \mathrm{ab}$ & $65 \mathrm{bc}$ \\
\hline Oryzalin AS & 6.7 & $103 a$ & $88 \mathrm{a}$ & $92 \mathrm{ab}$ & $94 \mathrm{ab}$ \\
\hline Oxyfluorfen $1.6 \mathrm{E}$ & 2.2 & $45 \mathrm{c}$ & $55 \mathrm{a}$ & $57 a b$ & $52 \mathrm{c}$ \\
\hline Simazine $80 \mathrm{~W}$ & 5.4 & $44 \mathrm{c}$ & $75 \mathrm{a}$ & $29 \mathrm{~b}$ & $49 c$ \\
\hline Norflurazon + diuron & $2.2+2.7$ & $67 a-c$ & $99 \mathrm{a}$ & $69 \mathrm{ab}$ & $78 \mathrm{a}-\mathrm{c}$ \\
\hline + Oxyfluorfen & $2.2+1.1$ & $55 \mathrm{bc}$ & $66 \mathrm{a}$ & $72 a b$ & $65 \mathrm{bc}$ \\
\hline+ Simazine & $2.2+2.7$ & $56 \mathrm{bc}$ & $91 \mathrm{a}$ & $78 \mathrm{ab}$ & $75 a-c$ \\
\hline Oryzalin + diuron & $3.4+2.7$ & $67 a-c$ & $99 \mathrm{a}$ & $99 \mathrm{a}$ & $88 \mathrm{ab}$ \\
\hline + Norflurazon & $3.4+2.2$ & $91 \mathrm{ab}$ & $93 \mathrm{a}$ & $52 \mathrm{ab}$ & $78 \mathrm{a}-\mathrm{c}$ \\
\hline + Oxyfluorfen & $3.4+1.1$ & $76 a-c$ & $90 \mathrm{a}$ & $90 a b$ & $85 a b$ \\
\hline + Simazine & $3.4+2.7$ & $98 \mathrm{a}$ & $97 \mathrm{a}$ & $110 \mathrm{a}$ & $101 \mathrm{a}$ \\
\hline
\end{tabular}

${ }^{2}$ Mean separation in columns by Duncan's multiple range test, $P \leq 0.05$.

controlled by fall-applied herbicides until early May, when summer annuals began to germinate. For diuron, norflurazon, and simazine, fall plus spring application did not increase the days of control over spring application alone (3-year averages).

Annual grass and broadleaf weeds grew in 1988, but annual broadleaves were dominant in 1989 and 1990. Diuron gave the most days of control (3-year averages) because it was effective against annual broadleaf weeds. Norflurazon and simazine were also effective against annual broadleaf weeds, but in 1990 they provided fewer days of control than diuron. This result was also shown in the lower 3-year averages for weed cover for simazine.

In 1988, there were significant differences in the days of acceptable annual weed control among herbicides and between single and tankmix applications (Table 2). Oryzalin used alone gave the most days of control, but the control provided by it was similar to that obtained with other treatments. Tank-mixing other herbicides with oryzalin at $3.4 \mathrm{~kg} \cdot \mathrm{ha}^{-1}$ did not increase the days of control compared to oryzalin alone at $6.7 \mathrm{~kg} \cdot \mathrm{ha}^{-1}$. Diuron, norflurazon, and oxyfluorfen were as effective when applied alone as when tank-mixed. Weed control with simazine was improved by tank-mixing with oryzalin. In 1989, no significant differences occurred in the days of control among the treatments. In 1990, weed control with simazine was again improved by tank-mixing with oryzalin.

When the data were averaged over 3 years, oryzalin controlled weeds longer than oxyfluorfen or simazine but not diuron or norflurazon. Tank-mixing oryzalin at $3.4 \mathrm{~kg} \cdot \mathrm{ha}^{-1}$ with oxyfluorfen at $1.1 \mathrm{~kg} \cdot \mathrm{ha}^{-1}$ or simazine at $2.7 \mathrm{~kg} \cdot \mathrm{ha}^{-1}$ did increase the days of control compared to using simazine or oxyfluorfen alone at full-label rate. Welker (1984) found improved weed control when simazine was combined with oryzalin. Tank-mixing diuron or norflurazon with oryzalin at $3.4 \mathrm{~kg} \cdot \mathrm{ha}^{-1} \mathrm{did}$ not increase the days of control compared to either herbicide used alone.

Fall herbicide application is effective against winter annuals, but it does not give extended summer annual weed control the next season (Kaps and Odneal, 1991). In the current study, splitting the herbicide application rate (fall plus spring) was not better than spring application alone. Growers are advised to make a spring preemergence application of herbicide at a rate recommended for their soil type. Treatment of weed escapes during the growing season and later in the year for winter annuals with a directed postemergence spray is advised also. Other work has shown that herbicide combinations and rotations provide a broader weed control spectrum with less chance for resistant weed populations (Welker, 1984; Welker and Meade, 1980). The current study showed that half-label rates of the tankmixed herbicides diuron, norflurazon, or oryzalin were as effective as full-label rates of these herbicides used alone. Weed control by oxyfluorfen or simazine was improved by tank-mixing with oryzalin.

\section{Literature Cited}

Cahoon,G.,M. Ellis, R. Williams, and L. Lockshin. 1991, Grapes: Production, management and marketing. Ohio Coop. Ext. Serv. Bul. 815.

Kaps, M.L. and M.B. Odneal. 1991. Fall-applied preemergent herbicides in a Missouri vineyard do not control annual weeds the following season.HortScience 26:1292-1293.

Welker, W.V. 1984. The effects of oryzalin alone andincombination withdiuron and simazine on young peach trees. HortScience 19:824-826.

Welker, W.V. and J.A. Meade. 1980. Evaluation of various orchard management systems. Proc. Northeast Weed Sci. Soc. 34:300-301. (Abstr.) 